\author{
Agata Wojciechowska \\ student \\ Lodz University of Technology \\ 116 Żeromskiego St., 90-924, Lodz, Poland \\ E-mail: 211496@edu.p.lodz.pl, ORCID: https://orcid.org/0000-0002-1529-9004
}

\title{
SOURCES OF STUDENTS' MOTIVATION TO TAKE UP PAID EMPLOYMENT DURING STUDYING
}

The article presents the results of the research aimed at identifying the sources of students' motivation to take up paid employment during the course of study. Motivation process and theoretical approaches towards its consideration - from the points of view of the content, of the process and based on the concept of reinforcement - are described. As for the content motivation is considered either as a function of pay, working time and working conditions, or as a function of autonomy and responsibility. The process approach focuses on the explanation of why people choose certain behavior in order to meet their needs and how they assess their satisfaction after achieving goals. Reinforcement concept explains the role of rewards in causing a change in behavior or maintaining unchanged behavior for some time. There are three areas of students' activity: educational, professional and personal one. For proper understanding of the concept of "professional activity" an overview of definitions concerning professional activity is done. The main assumptions of the research were that students undertake random jobs guided solely by remuneration. They do not pay attention whether there is any connection with the field of their study. The examination involved 478 students from 15 cities from all over Poland, who study at 43 universities. The research showed that the factors that influenced students' decisions to take up a job are first of all the following: the need for earning, as well as the desire to gain experience and the need to become a financially independent person. Respondents, who declare compliance of their work with the field of study, additionally indicate the possibility of continuous self development. For the students, who declare work in line with their interest, self-fulfillment is a key focus. students.

Keywords: motivation and its sources, professional activity of students, motivation factors for working

JEL Classification: A14, J21, J42.

Introduction. The situation on the labor market is often described as extremely beneficial for an employee. Demand exceeds supply - this means that we deal with reality, in which "work is looking for a man", and not the other way round. This is the position of, among others, Cezary Kaźmierczak, who summed up the events of the recent years with the following opinion: "the market, in which employers dictated the terms and conditions is behind us". This means that students also have the opportunity to take up paid employment on favorable terms. The purpose of this study is to present the results of the research aimed at identifying the professional activity of students and factors that motivate them to undertake it. The research was conducted with the use of research desk method and a survey sent to respondents via social media.

The essence of motivation. Motivation is an extremely important element of human resource management in contemporary organizations. Therefore, it is worth knowing exactly what it involves. "Motivation is derived from the Latin word "motus" and English word "move", which means move from place, set in motion, encourage, influence someone and stimulate activities" (Sekuła, 2008). In order to understand this basic concept properly, within the framework of this study, a literature review was carried out. It showed multiple approaches and definitions. Therefore, for the purposes of this article, it was assumed (like M. Kopertyńska) that motivation is "an internal process, which determines the direction of the employee's activities and the amount of energy that can be provided by an employee to achieve goals and tasks that set this direction" (Kopertyńska, 2009).

Motivation is very important in a workplace, because it affects the results achieved by a single employee. According to R. W. Griffin (Griffin, 2017), in addition to motivation, equally important factors are: "opportunities (ability to perform a certain job) and work environment (resources

\footnotetext{
๑ Wojciechowska A., 2020
} 
necessary to perform a job)". However, in the absence of capacity a manager can solve the problem by ensuring training for an employee, who needs it or replacing an employee by another employee, but in case of resources - introduction of the right change is more difficult when we talk about insufficient (wrong motivation or lack of motivation). It is "elusive", but defines the results of work.

In order to understand how the motivated behavior appears, the motivation scheme was used (Figure 1).

The motivation process is initiated by the need of feeling, concerning the lack of something. This prompts a person, who feels it, to seek a way to meet such a need. Then, a person chooses one solution (among all available solutions) and implements it. The next step is to assess the level of meeting the need. Even if the goal is achieved in a satisfactory degree, after some time, such a person will (again) start to determine the next needs and look for a way to meet them. The process will be repeated.

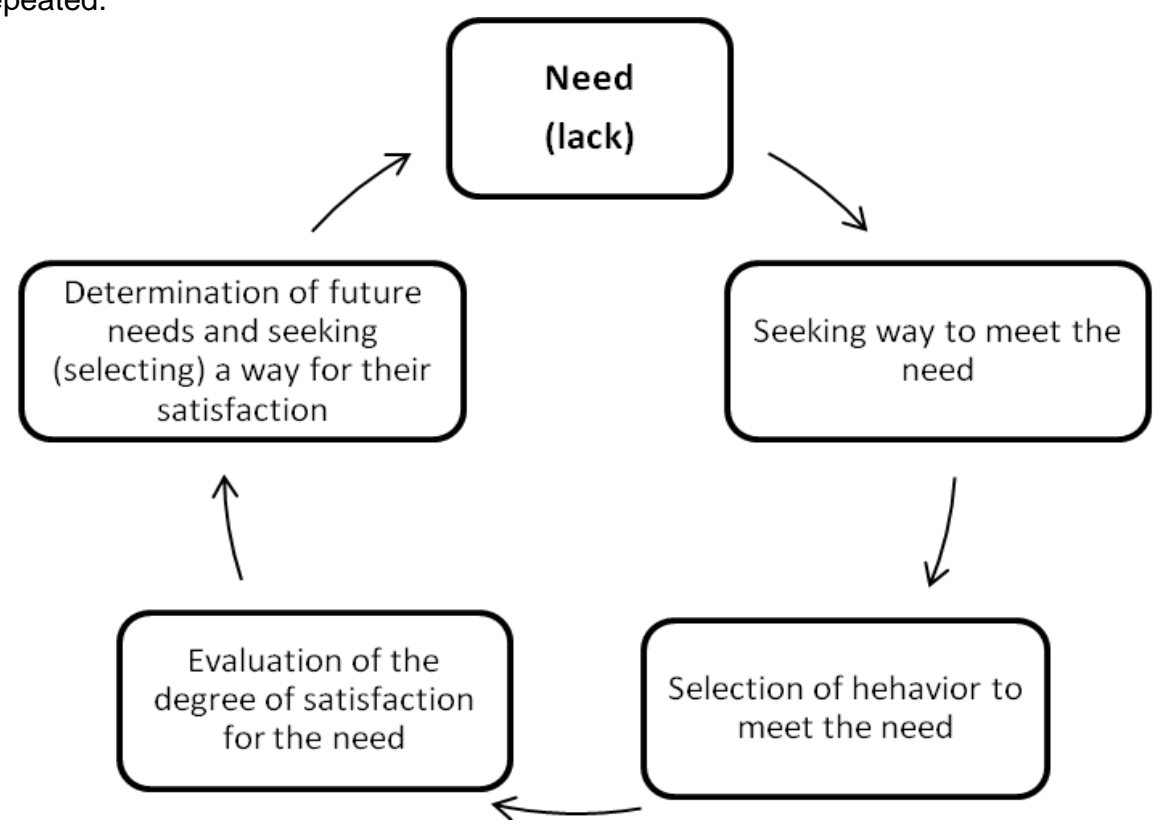

Figure 1. Motivation process scheme

Source: own study based on (Griffin, 2017)

R. W. Griffin (Griffin, 2017) presents different approaches towards motivation process:

- From the content,

- From the process,

- Based on the concept of reinforcement.

The content-based motivating approach focuses on the first part of the motivation process - on needs and feeling of deficiency associated with them. More precisely, the content-based approach attempts to answer the question: "What factors motivate people to work?". There are two views concerning the content-based motivation. According to the first one, motivation is a function of pay, working time and working conditions, while according to the second one, motivation is a function of autonomy and responsibility. Two widely known approaches to content-based motivation include the theory of hierarchy of needs and two-factor theory.

Taking into account motivation from the side of the process, we deal with the method of its creation. Instead of trying to identify or calculate motivational stimuli, the process approach focuses on the explanation why people choose certain behaviors in order to meet their needs and how they assess their satisfaction after achieving goals. Popular process-based motivation approaches include the theory of expectations, the theory of justice and the theory of setting goals. 
A glance based on the concept of reinforcement explains the role of rewards in causing a change in behavior or maintaining unchanged behavior for some time. More specifically, according to the theory of reinforcement, the behavior connected with rewards is likely to be repeated, and a repeated behavior directly associated with punishment is less likely." (Griffin, 2017)

Motives of action affecting the realization of the determined goals are individual for each person. From the organization's point of view, it is very important to constantly analyze the needs and motives of employees. Thanks to the adaptation of the right sets of motivation solutions for them, the company can count on increased involvement and motivation of employees, and thus the development of the whole organization. These solutions should result from a thorough analysis and take into account the expectations and needs of employees. According to the authors of the article entitled 'Commitment to organization and motivation to work and the level of employees' materialism - the intermediary role of job satisfaction", sources of motivation to work can be sought in both internal (e.g. satisfaction) and external (e.g. remuneration) factors" (Peplińska at al., 2018). Sources of motivation are evolving in individual development of a person. Particularly interesting are aspects concerning the motivation to work of young, studying people, who represent $Z$ generation (Stankiewicz-Mróz, 2020).

Professional activity of students. Students are people, who stand on the threshold of adulthood. It often happens that (at this moment) they must count on their independence for the first time. It is also the time when "young people strive to achieve psychological maturity in order to face the challenges of adult life. A young person can pursue his or her own lifestyle and determine his or her place in the surrounding world, because previous individuals only prepared an outline of their plans and thought about what they would like to do with their lives. Now, after obtaining the necessary education (released by the family into the wide world), they can bring their plans into action" (Turner \& Helms, 1999).

There are three areas of students' activity:

- educational,

- professional,

- personal.

The sphere based on the concentration of attention and activity of students influences the shape of their future career path and its development. Therefore, it is important to properly understand the concept of "professional activity". In order to explain it, a summary of selected definitions is presented in Table 1.

Overview of definitions concerning professional activity

Table 1

\begin{tabular}{|c|c|}
\hline Author & Definition \\
\hline $\begin{array}{l}\text { T. Nowacki } \\
\text { K. Korabiowa- } \\
\text { Nowacka } \\
\text { B. Baraniak } \\
\text { (Nowacki at al., 2000) }\end{array}$ & $\begin{array}{l}\text { "individual's path of professional development from the phase of familiarization with } \\
\text { areas of human economic and cultural activity, through the phase of general } \\
\text { vocational preparation to the period of vocational preparation" }\end{array}$ \\
\hline $\begin{array}{l}\text { Z. Wiatrowski } \\
\text { (Wiatrowski, 2005) }\end{array}$ & $\begin{array}{l}\text { "process of growing and learning based on all cases of professional behavior. This } \\
\text { is a gradual increase and changes in the individual's ability to conduct certain types } \\
\text { of professional behavior" }\end{array}$ \\
\hline $\begin{array}{l}\text { K. Czarnecki } \\
\text { (Czarnecki, 2005) }\end{array}$ & $\begin{array}{l}\text { "socially desirable and targeted process of human quantitative and qualitative } \\
\text { changes that condition his conscious, purposeful, active, controlled and responsible } \\
\text { participation in shaping himself, as well as his close and distant surroundings" }\end{array}$ \\
\hline Z. Wołk (Wołk, 2005) & $\begin{array}{l}\text { "professional development is a self-improvement in both general and professional } \\
\text { terms. It is perceived as the acquisition of more and more new professional } \\
\text { features that enables to solve more and more comprehensive problems during the } \\
\text { course of work" }\end{array}$ \\
\hline
\end{tabular}

Source: own study 
Currently, students start their professional activity relatively early in order to become competitive in relation to their peers. On the other hand, they treat their workplace" as a field providing opportunities for the development and accumulation of resources, but not necessarily as a source of identification" (Domecka \& Mrozowicki, 2008). Their professional activity is mainly a response to the needs of the labor market and requirements of future entrepreneurs, who expect not only educated, but also experienced employees." (Krause, 2012) .An additional advantage is the acquisition and development of specific skills that are useful for career development.

Research methodology. The aim of the study was to identify the sources of students' motivation to take up paid employment during their studies.

The research put the $\mathrm{H} .1$ hypothesis as follows The research put the $\mathrm{H} .1$ hypothesis as follows: students undertake paid work that is not related to the field of their studies. H.1.1 hypothesis was also formulated: the work is accidental and its selection is only determined by financial considerations - as a consequence, the work does not enable to develop competences relevant to the student's field of study. The research was conducted with the use of a questionnaire sent directly to students via Internet and through its publication on websites associating students from various universities. The research involved 478 students from 15 cities from all over Poland, studying at 43 universities. Selection for a sample group was purposeful and it depended on the availability of respondents. The study was carried out in the period from 4 to 10 May 2020.

Socio-demographic analysis of the examined population. Research analysis of a given sample group was carried out in terms of significant socio-demographic characteristics such as gender, age, field of study, university and housing situation.

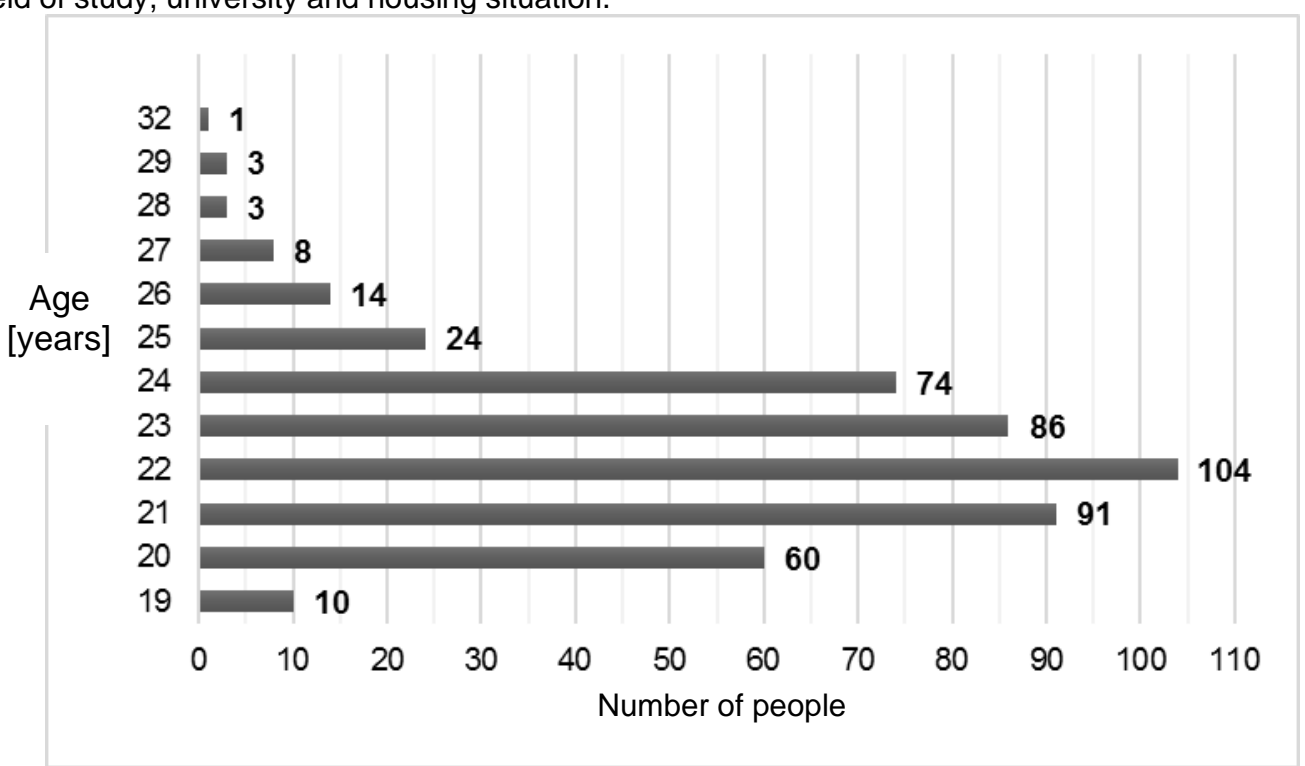

Source: own study

The first question in the survey concerned respondents' gender. The study sample included 378 women and 101 men.

The second point in the survey was the specification of respondents' age. The structure of the examined group by age is presented in Figure 1. In the studied group, the dominant category was presented by respondents aged $21-24$ (74\%).

The third focus in the survey was the name of the field of study. Due to a great variety in the fields of study given by respondents, they were grouped, as it's shown in Figure 2. Most of the respondents (as many as 140) study technical disciplines. Second group constitutes students of medical and health disciplines - 122 persons. Then, there were people from the following fields: 
economics -87 , social -71 , humanities -26 , exact science -12 , natural sciences -10 , agricultural, forestry and veterinary -5 , as well as from other disciplines -5 .

In the fourth point of the survey, the respondents indicated the name of their universities. In the studied sample, the dominant category constituted students from universities - 216 persons, technical colleges - 137 and medical colleges - 118. Additionally, there were 26 students from economics colleges, 3 from art colleges, 3 from natural science colleges and 2 from pedagogical colleges.

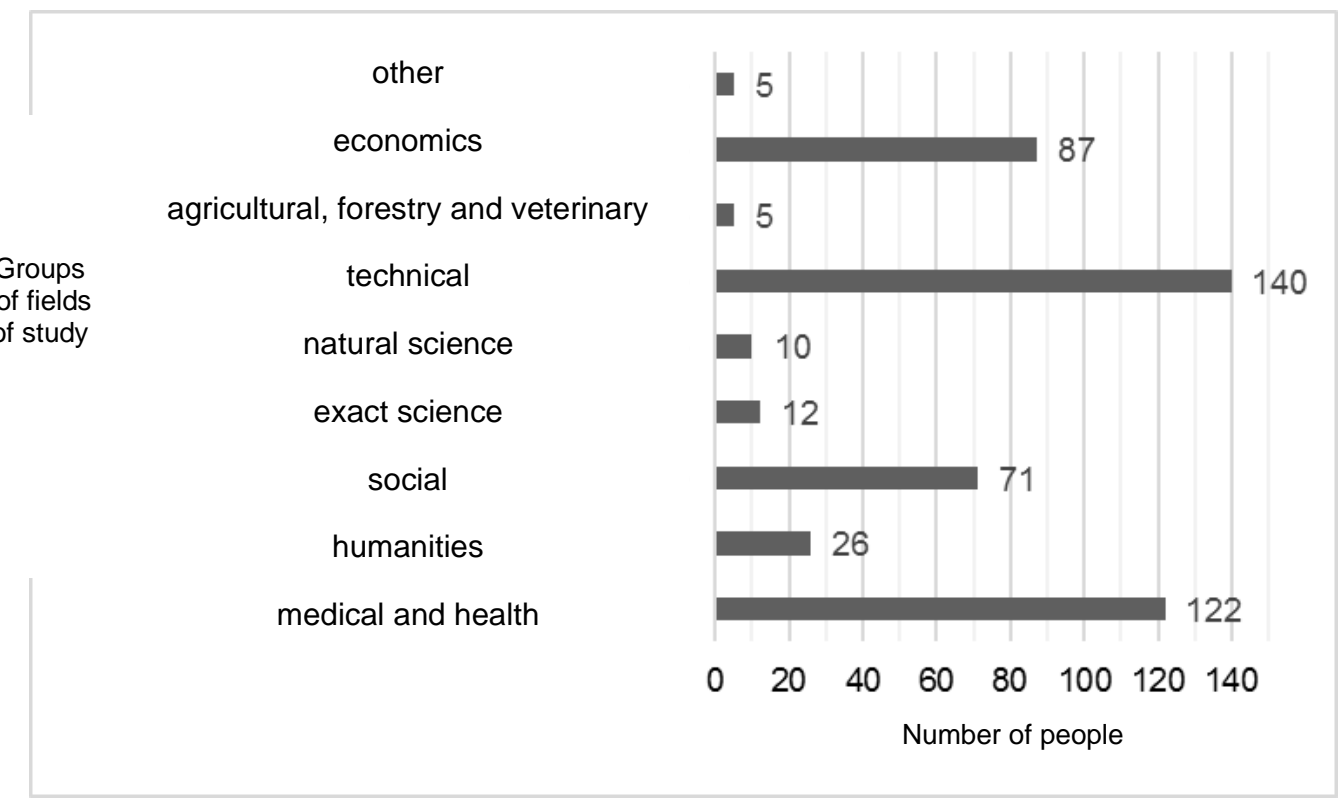

Figure 2. Structure of the studied population by field of study

Source: own study

One of the important socio-demographic features (due to the examined subject) is the housing situation of the respondents. In the examined group: 218 people rent a flat, 160 live with their parents, and 100 live in a dormitory.

Analysis of the obtained results. The above-described group was asked to complete a survey, including seven questions. The first question concerned professional activity of the respondents.

In the examined group, $56 \%$ of respondents (266 people) are currently working, while $44 \%$ (212 people) are not working. Such a high percentage of unemployed students can be connected with the coronavirus pandemic that has recently caused a wave of dismissals in all sectors of the economy. Only working students were the subject of interest in the further part of research (those 266 people).

However, the preliminary analysis showed that there were 7 incorrectly completed questionnaires in this group. They were rejected. The remaining surveys (259) were further analyzed. In question No. 2 the respondents were asked to indicate their labor sector from the list of 16 sectors of the economy or add the missing sector. Most of the respondents (as many as 70) work in the customer service and sales sector. Another large group consists of students employed in gastronomy -28 , administration -21 , services -21 , education -18 , production -18 , public health and social work sector - 17, as well as financial and insurance consulting - 16. Less than 10 respondents work in other sectors: communication - 7 persons, art, entertainment and recreation 7 , transport -7 , accounting -6 , construction -5 , IT -4 , logistics -3 , technologies -3 , energy supply -2 , as well as audit, hostels, marketing and PR, real estates and agriculture -1 person per each sector). Such a high percentage of students working in the customer service and sales may result from several reasons: 
- High demand for employees - many new jobs in small private enterprises, as well as departments, branches or showrooms of chain stores located in large complexes of shopping malls in almost every city;

- Large number of jobs - currently, there are many shops or showrooms in every city. They need people to work as salesmen or customer service employees;

- Accessibility - companies usually have branches in larger trade centers, which are easily accessible;

- Flexible work schedule - students can reconcile education with work, thanks to the possibility of determining their own work schedule;

- Contract of mandate - students usually work on the basis of a contract of mandate, which is beneficial for both parties - an employer does not have to pay contributions, while the employee receives a higher salary.

The third question concerned the compliance of current work with the student's field of study. Nearly half of the respondents (as many as 148) believe that their current work is not related to their field of study. However, the remaining 111 people claim that their work is consistent with their education. This means that persons from this second group have the opportunity to develop competences relevant to their current education, and gain experience in this direction, which is often required by the employer.

In the fourth question respondents gave the answers regarding the compliance of their work with their interests. The majority - 158 people - declared compliance of their current work with their interests. On the other hand, 101 respondents disagree with the fact that their interest and work coincide. This may mean that the selection of their job was mainly determined by financial considerations.

In question No. 7 the respondents determined whether it is easy for them to combine work with parallel university education. Most of the respondents indicated that combination of work with studies is not difficult for them (175 persons). 84 respondents had the opposite opinion. The predominance of affirmative answers may result from flexible work schedules offered by the employer, thanks to which the employee can adapt it to his/her course of studies.

The next two questions were based on the Likert scale. Students expressed their opinion about the significance of the factors listed in the survey for the decision to take up a job and determination of the validity of motivating factors at work. include:

It was assumed that the factors that have the greatest impact on the decision to take up a job

- Need for earnings,

- Willingness to gain experience,

- Willingness to be independent,

- Need to complete mandatory internships.

The structure of respondents' answers is presented in Table 2.

Structure of answers regarding the selected factor

Table 2 that influences the decision to take up a job

\begin{tabular}{|c|c|c|c|c|c|}
\hline \multirow{2}{*}{$\begin{array}{l}\text { Selected factors that } \\
\text { influence the decision } \\
\text { to take up a job }\end{array}$} & \multicolumn{5}{|c|}{ Answer structure [\%] } \\
\hline & $\begin{array}{l}\text { It is very } \\
\text { important }\end{array}$ & $\begin{array}{c}\text { It is } \\
\text { important }\end{array}$ & $\begin{array}{l}\text { I have no } \\
\text { opinion }\end{array}$ & $\begin{array}{l}\text { It has little } \\
\text { importance }\end{array}$ & $\begin{array}{l}\text { It does not } \\
\text { matter }\end{array}$ \\
\hline Need for earnings & $57 \%$ & $20 \%$ & $14 \%$ & $6 \%$ & $3 \%$ \\
\hline $\begin{array}{l}\text { Willingness to gain } \\
\text { experience }\end{array}$ & $46 \%$ & $21 \%$ & $19 \%$ & $7 \%$ & $7 \%$ \\
\hline $\begin{array}{l}\text { Willingness to be } \\
\text { independent }\end{array}$ & $53 \%$ & $19 \%$ & $21 \%$ & $6 \%$ & $1 \%$ \\
\hline $\begin{array}{c}\text { Need to complete } \\
\text { mandatory internships }\end{array}$ & $3 \%$ & $5 \%$ & $11 \%$ & $9 \%$ & $72 \%$ \\
\hline
\end{tabular}

Source: own study 
The above results show that the majority of students think that the need of earnings $(57 \%)$, willingness to gain experience (46\%) and willingness to be independent $(53 \%)$ is very important for them when making decision about taking up a job. Almost $3 / 4$ of the respondents $(72 \%)$ also think that (among the listed factors) the need to complete mandatory internship is not relevant to them. This means that students rarely go work just because they must complete internships during their studies. They more often start work, because they want to earn, become independent and gain necessary experience - at the same time, they take advantage of the opportunity to complete a student internship. It is also worth noting that there is a relatively large group of respondents, who have no opinion about the significance of the presented factors. In the case of completing some mandatory internships, it is $11 \%$ of respondents, for the purpose of earning $-14 \%$, for the desire to gain experience $-19 \%$, while for the willingness to be independent $-21 \%$. This means that virtually every fifth respondent is not able to determine the importance of experience and financial self-sufficiency for him/her.

Based on the analysis of literature, a list of the most frequently used motivational factors was prepared. The respondents were asked to evaluate their significance in question No. 6. Respondents usually indicated: a nice atmosphere in the workplace (58\%), remuneration (55\%), flexible working time $(54 \%)$ and the opportunity to gain new experience (51\%). In their case, some analogy can be observed. In total, over $76 \%$ of respondents think that the above-mentioned factors are motivational. Additionally, $51 \%$ of respondents from this group believe that they are very important. Taking into account all factors, the smallest percentage of the sum of "is very important" and "is important" answers received: presence of friends (e.g. from studies) in the company (17\%), possibility of remote work (32\%) and non-wage benefits (33\%). As many as $39 \%$ of respondents stated that the presence of friends (e.g. from university) in the company does not matter to them.

Three lists were made in order to check the change of the answer structure depending on the specific parameter. Table 3 presents the relation between the housing situation and the fact of employment.

Table 3

Structure of answers regarding the relation between the housing situation and employment status

\begin{tabular}{|c|c|c|}
\hline Housing situation & Number of working students & Number of unemployed students \\
\hline Live in a dormitory & 52 & 46 \\
\hline Live with parents & 79 & 80 \\
\hline Rent a flat & 128 & 86 \\
\hline
\end{tabular}

Source: own study

As we note, the number of employed and unemployed persons is the most similar in a situation, when the respondent lives with his or her parents. This can be caused by the fact that parents cover all the costs associated with house and utilities - student without this type of expenses does not feel the need to earn money.

There is a slight difference when a respondent lives in a dormitory. This may be connected with the possibility of receiving a social scholarship from the university. Thanks to this scholarship, the student can pay the rent and therefore, he or she does not have to work.

The last option deviates from the above-described trend, i.e. when the student rents a flat. In this case, we have the most working respondents. Such a situation may result from high rental cost in the city. The respondent is forced to take up a job.

In the next summary, the structure of obtained answers regarding a selected motivating factor at work was checked - depending on the respondents, who declare compliance of their work with the field of study.

The results do not disagree with the general trends that can be observed in all the respondents, because differences usually have only a few percentage points. The most important for respondents, who declare compliance of their work with the field of study, were the following factors: opportunity to gain new experience $(69 \%)$, nice atmosphere in the workplace $(62 \%)$, possibility of continuous development (58\%), flexible working time $(53 \%)$ and remuneration $(49 \%)$. The presented results may 
indicate that students consider work in such a position in the future. Contrary to popular belief, money does not occupy top position in this ranking - it is only important for every second respondent.

In the last list, the structure of answers regarding the selected motivating factor at work in connection with the declared compliance of work with the interests of respondents was checked. Just like in the previous case, the results do not diverge from the general trends resulting from the declaration of all respondents, because differences usually have only a few percentage points. The following factors were the most important for the respondents, who declare the compliance of their work with interests: opportunity to gain new experience $(65 \%)$, nice atmosphere in the workplace $(57 \%)$, possibility of continuous development (56\%), flexible working time $(51 \%)$ and self-fulfillment $(50 \%)$. This may indicate that remuneration is of secondary importance for students, who have the opportunity to deepen their interests in their current position. For them, the most important is satisfying work in a friendly environment and a feeling of fulfillment.

Conclusions. The surveyed students indicated that the factors that influenced their decision to take up a job were (primarily) the need for earning, willingness to gain experience and the willingness to be independent. On the other hand, the need to complete their mandatory internships does not matter to them.

The majority of students indicate that the following factors constitute the most important motivating factors: nice atmosphere at work, remuneration, flexible working hours and opportunity to gain new experience. The respondents, who declare compliance of their work with the field of study, indicate also the possibility of continuous development. On the other hand, for respondents working in a position consistent with their interests, self-fulfillment (aside from the possibility of continuous development) is a decisive factor. Employees had various opinions about the possibility of remote work, work based on an employment contract, quick recruitment process and non-wage benefits. The percentage of respondents' answers was not as varied as in previous cases and there were no clear trends.

In summary, the $\mathrm{H} .1$ hypothesis has been verified positively. Over half of the students (57\%) take up a job that is not connected with their field of studies. In the majority of cases, their work is not consistent with their field of study, but is consistent with their interests. One of the main factors deciding about taking up a job is the need to earn money. This means that the H.1.1 hypothesis (work is accidental, and financial factors decide on its selection - as a consequence, it does not enable to develop relevant competences) was also confirmed in the study.

\section{References}

1. Sekula, Z. (2008). Motivating to work. Theories and instruments. Warsaw: PWE. (in Polish)

2. Kopertynska, M. (2009). Motivating employees - theory and practice. Warsaw: Placet Publishing Agency. (in Polish)

3. Griffin, W. R. (2017). Fundamentals of organization management. Warsaw: PWN Scientific Publishing House. (in Polish)

4. Peplinska, A., Godlewska-Werner, D., Celinska, S., Nietskazh, Z., \& Polomsky, P. (2018). Attachment to the organization and motivation to work versus the level of employee's materialism - the mediating role of job satisfaction. Human Resources Management, 1(120), 11-30. (in Polish)

5. Stankievich-Mruz, A. (2020). Perception of Work Flexibility among Students as Representatives of Generation Z and Employers from the SME Sector. Human Resources Management, 1(132), 49-63. doi: https://doi.org/10.5604/01.3001.0013.8778.

6. Turner, J. S., Helms, D. B. (1999). Human development. Warsaw: WSiP. (in Polish)

7. Nowatsky, T., Korabiovska-Novatska, K., Baraniak, B. (2000). A new dictionary of work pedagogy. Warsaw. (in Polish)

8. Viatrovsky, Z. (2005). Professional activity in the context of human professional development. Professiology Problems, 1, 25-33. (in Polish)

9. Charnetsky, K. (2005). Professiology as a separate field of knowledge and research on professional human development. Professiology Problems, 1, 13-24. (in Polish)

10. Volk, Z. (2005). Professional development in the context of life. Professiology Problems, 1, 35-47. (in Polish) 
11. Dometska, M., Mrozovitsky, A. (2008). Workers and business people. Models of professional careers and social change in Poland. Qualitative Sociology Review, 1(4), 136-155. (in Polish)

12. Krause, E. (2012). Professional career development of students - contexts and achievements. Bydgoszcz: University of Kazimierz Wielki Publishing House. (in Polish)

\section{Література}

1. Sekuła Z. Motywowanie do pracy. Teorie i instrumenty. Warszawa: PWE, 2008. 324 s.

2. Kopertyńska M., Motywowanie pracowników teoria i praktyka. Warszawa: Placet Publishing Agency, 2009. $320 \mathrm{~s}$

3. Griffin W. R. Podstawy zarządzania organizacjami, Warszawa: Wydawnictwo Naukowe PWN, 2017. $743 \mathrm{~s}$.

4. Peplińska A., Godlewska-Werner D., Celińska S., Nieckarz Z., Połomski P., Przywiązanie do organizacji i motywacja do pracy a poziom materializmu pracowników - pośrednicząca rola satysfakcji z pracy. Zarzadzanie Zasobami Ludzkimi. 2018. Is. 1(120). S. 11-30

5. Stankiewicz-Mróz A., Perception of Work Flexibility among Students as Representatives of Generation $Z$ and Employers from the SME Sector. Human Resources Management. 2020. No. 1 (132). S. 49-63. DOI: https://doi.org/10.5604/01.3001.0013.8778.

6. Turner J. S., Helms D. B., Rozwój człowieka. Warsaw: WSiP, 1999. 725 s.

7. Nowacki T., Korabiowska-Nowacka K., Baraniak B. Nowy słownik pedagogiki pracy. Warsaw, 2000. $324 \mathrm{~s}$.

8. Wiatrowski Z. Działalność zawodoznawcza w kontekście rozwoju zawodowego człowieka. Problemy Profesjologii. 2005. No. 1. S. 25-33.

9. Czarnecki K. Profesjologia jako wyodrębniająca się dziedzina wiedzy i badań naukowych o zawodowym rozwoju człowieka. Problemy Profesjologi. 2005. No. 1. S. 13-24.

10. Wołk Z. Rozwój zawodowy na tle życia. Problemy Profesjologii. 2005. No. 1. S.35-47.

11. Domecka M., Mrozowicki A. Robotnicy i ludzie biznesu. Wzory karier zawodowych a zmiana społeczna w Polsce. Przegląd Socjologii Jakościowej. 2008. No. 1, vol. IV. S.136-155.

12. Krause E., Rozwój kariery zawodowej studentów - konteksty i dokonania. Bydgoszcz: University of Kazimierz Wielki Publishing House, 2012. 207 s.

\section{Агата Войчеховська студентка \\ Лодзький технічний університет вул. Жеромського, 116, м. Лодзь, 90-924, Польща E-mail:211496@edu.p.lodz.pl, ORCID: https://orcid.org/0000-0002-1529-9004 \\ ДЖЕРЕЛА МОТИВАЦІЇ СТУДЕНТІВ ДО ВЛАШТУВАННЯ НА ОПЛАЧУВАНУ РОБОТУ ПІД ЧАС НАВЧАННЯ}

У статті представлено результати дослідження, пов'язаного з виявленням джерел мотивації студентів влаштовуватися на оплачувану роботу в процесі навчання. Описується процес мотивації теоретичні підходи до його розгляду - з позиції змісту, процесу та концепції самопосилання. У першому випадку мотивація розглядається або як функція оплати, робочого часу і умов праці, або як функція незалежності і відповідальності. Процесний підхід фокусується на поясненні того, чому люди вибирають певну поведінку для задоволення своїх потреб і як вони оцінюють своє задоволення після досягнення цілей. Концепція самопосилення пояснює роль винагороди в зміні поведінки або збереження незмінного поведінки протягом певного часу. Активність студентів включає три основні напрямки: освітню, професійну і особисту. У роботі наводиться огляд визначень, що стосуються професійної діяльності. Основні допущення дослідження полягали в тому, що студенти обирають випадкову роботу, керуючись виключно запропонованим винагородою. Вони не звертають уваги на те, чи є зв'язок виконуваної роботи з їх навчанням. У тестуванні взяли участь 478 студентів з 15 міст з усієї Польщі, які навчаються в 43 університетах. Дослідження показало, що фрактори, які вплинули на рішення студентів про працевлаштування, - це, перш за все, потреба в заробітку, а також бажання отримати досвід і стати фінансово незалежним. Респонденти, для яких найбільш важливою є відповідність роботи обраній 
спеціальності, додатково підкреслювали можливість постійного саморозвитку. Для студентів, які обрали роботу, що відповідає їх інтересам, ключовим пріоритетом була самореалізація.

Ключові слова: мотивація і ії джерела, професійна діяльність студентів, фрактори мотивації працюючих студентів.

JEL Classification: A14, J21, J42.

Агата Войчеховская

студентка

Лодзинский технический университет

ул. Жеромского, 116, г. Лодзь, 90-924, Польша

E-mail: 211496@edu.p.lodz.pl, ORCID: https://orcid.org/0000-0002-1529-9004

\section{ИСТОЧНИКИ МОТИВАЦИИ СТУДЕНТОВ К УСТРОЙСТВУ НА ОПЛАЧИВАЕМУЮ РАБОТУ ВО ВРЕМЯ ОБУЧЕНИЯ}

В статье представлены результаты исследования, связанного с выявлением источников мотивации студентов устраиваться на оплачиваемую работу в процессе обучения. Описывается процесс мотивации и теоретические подходы к его рассмотрению - с позиции содержания, процесса и концепции самоусиления. В первом случае мотивация рассматривается либо как функция оплаты, рабочего времени и условий труда, либо как функция независимости и ответственности. Процессный подход фокусируется на объяснении того, почему люди выбирают определенное поведение для удовлетворения своих потребностей и как они оценивают свое удовлетворение после достижения целей. Концепция самоусиления объясняет роль вознаграждения в изменении поведения или сохранении неизменного поведения в течение определенного времени. Активность студентов включает три направления: образовательную, профессиональную и личную. В работе приводится обзор определений, касающихся профессиональной деятельности. Основные допущения исследования заключались в том, что студенты берутся на случайную работу, руководствуясь исключительно предложенным вознаграждением. Они не обращают внимания на то, есть ли связь выполняемой работы с областью их образования. В тестировании приняли участие 478 студентов из 15 городов со всей Польши, обучающихся в 43 университетах. Исследование показало, что фракторы, которые повлияли на решение студентов о трудоустройстве, - это, прежде всего, потребность в заработке, а также желание получить опыт и стать финансово независимым. Респонденты, для которых важно соответствие работы выбранной специальности, дополнительно подчеркивали возможность постоянного саморазвития. Для студентов, которые выбрали работу, соответствующую их интересам, ключевым приоритетом являлась самореализация.

Ключевые слова: мотивация и ее источники, профессиональная деятельность студентов, фракторы мотивации работающих студентов.

JEL Classification: A14, J21, J42. 